D. S. Bukreieva, orcid.org/0000-0003-3175-5193
Dnipro University of Technology, Dnipro, Ukraine, e-mail: bukreieva.d.s@nmu.one

\title{
PECULIARITIES OF FORMATION OF THE COUNTRY'S INNOVATIVE ENVIRONMENT BASED ON COMPLEX ANALYSIS OF RESOURCES OF INNOVATION
}

Purpose. To study the regularities and tendencies of the influence of institutional factors on the country's innovative potential in order to determine the ways of its increase on the basis of studying the indicators of "input" of the level of development of the institutional structure of the country's innovative potential and develop a conceptual model for the effective functioning of the innovation environment.

Methodology. In solving the tasks, the following methods were used: scientific abstraction - in determining the main problems of the development of national innovation systems; critical analysis, generalization, systematization - to evaluate the effectiveness of innovation policy of countries and to compare them; ranking and statistical analysis - to determine the relationship between individual indicators of the global innovation index and the level of development of the country.

Findings. The ranking of European countries by the main indicators of innovation resources has been carried out in terms of the effectiveness of conducting and using research and development. The "bottlenecks" which constrain the increase in Ukraine's innovative potential are determined based on the analysis of the "input" indicators of the institutional structure development level of innovation potential. A high degree of dependence of the country's economic development on its innovative potential is demonstrated. The main directions of increasing the innovative potential of Ukraine on the basis of effective management of innovation resources are formulated. It has been proved that the factors of the environment, namely the political and economic crises, caused by conducting an anti-terrorist operation in the east of the country, are not those that inhibit its innovative development. The main directions of increasing the innovative potential of Ukraine on the basis of efficient management of innovation resources are formulated. The conceptual model for the effective functioning of the innovation environment, which is aimed at increasing the intersectoral coordination of its subjects in order to adapt them to the actual conditions of a country's development, is developed.

Originality. The peculiarities of the formation of the laws of innovation development on the basis of complex comparative analysis of the indicators of the "input" of the level of development of the institutional structure of the country's innovative potential have been established, which has allowed identifying the factors that are determining in increasing the innovative potential of Ukraine and, on this basis, developing a conceptual model for the effective functioning of the innovation environment.

Practical value. The obtained results allowed formulating the main priority directions of development in the field of innovation management taking into account neutralization of the "bottlenecks"of the country's innovative potential.

Keywords: innovation potential, global innovation index, resources of innovations, innovation environment, indicative analysis

Introduction. A priority of economic research for all developed countries and relevant international organizations involves problems of effective management of increasing innovation potential in order to develop a national innovation environment. Forecasts of long-term economic growth are based on the assessment of the efficiency of the use of accumulated human capital and the development of the country's innovation environment. It should be note that effective management of innovation potential allows creating a basis for successful integration of the country into socio-economic processes. Given this, the European integration processes of Ukraine determine the solution of the following tasks: ensuring the competitiveness of the national economy and increasing its growth rates; raising social and environmental standards and solving the problems which occur in these areas; increasing the country's export potential and guaranteeing its economic security, and others. One of the solutions to these problems is the formation and implementation of an innovative development model since the experience of many foreign countries shows that the presence of a high innovative potential is a necessary factor for economic growth.

Literature review. The condition of innovative development is the institutional conditionality of innovation processes, regulation at all levels of interaction of innovators, institutions, the state, the market and the enterprise. The works by Tarapuez E., Ramiro B. are devoted to the institutional regulation of innovation and analysis of institutional constraints that hinder their development. Garcia A; García M. and Dias argue that the peculiarities of the development of leading national innovation systems are determined by factors that stimulate the intensification of innovation processes.

(C) Bukreieva D. S., 2020
In turn, the works by Kraus N. M. claim that the innovative economy through the prism of institutionalism should be interpreted as a set of interconnected and interacting structures that are engaged in the production and commercialization of scientific knowledge and technology within national borders. Kurylo L. I. emphasizes the effectiveness of the factors of the institutional environment that contribute to the competitive development of the country, while Lytvynenko N.I. brings a focus on the problems of the influence of the institutional environment on the socio-economic development of the country.

However, despite the fairly wide range of existing research, insufficient attention is paid to establishing the laws of innovation development based on an indicative analysis of the institutional structure development level of the country's innovation potential, which determines the relevance of this study.

Purpose. The purpose of the research is to study the regularities and tendencies of impact factors regarding the country's innovative potential in order to identify the ways of its improvement and conceptual model development of the innovation environment effective functioning, aimed at increasing the intersectoral coordination of its subjects.

Results. The rating approach is increasingly used for the systematic study on economic development issues in world practice. There are various methods for measuring innovation potential, the most famous of which is the Global Innovation Index (GII), calculated by the INSEAD Business School, Cornell University and the World Intellectual Property Organization [1]; Subindex of the innovative potential of the Global Competitiveness Index, calculated by the World Economic Forum [2]; World BankIncome Group Classification [3]. These international indicators of innovation are becoming an important tool for evaluating the effectiveness of state innovation policy. 
Today, as shown by the analysis of statistical data [1], the influence of innovation development factors increases dramatically, since at present, the share of new knowledge, which is embodied in technology, equipment, personnel education, organization and production management, accounts for up to $90 \%$ of GDP growth.

Regional leaders in the field of innovation according to the Global Innovation Index-2019 [1] are:

- Europe (EUR): Switzerland ( $1^{\text {st }}$ rank), Sweden ( $2^{\text {nd }}$ rank) and the Netherlands ( $4^{\text {th }}$ rank);

Southeast Asia and Oceania (SEAO): Singapore ( $8^{\text {th }}$ rank), Korea (11 ${ }^{\text {th }}$ rank), Gong-Kong ( $13^{\text {th }}$ rank);

- Central and South Asia (CSA): India (52 ${ }^{\text {nd }}$ rank), Iran (61 ${ }^{\text {st }}$ rank), Kazakhstan ( $79^{\text {th }}$ rank);

- North Africa and West Asia (NAWA): Israel (10 ${ }^{\text {th }}$ rank), Cyprus (28 $8^{\text {th }}$ rank), the United Arab Emirates ( $36^{\text {th }}$ rank);

- Sub-Saharan Africa (SSF): South Africa (53 ${ }^{\text {rd }}$ rank), Kenya ( $77^{\text {th }}$ rank), Mauritius ( $82^{\text {nd }}$ rank);

North America (NAC): the USA ( $3^{\text {rd }}$ rank), Canada (16 ${ }^{\text {th }}$ rank);

- Latin America and the Caribbean (LCN): Chile ( $51^{s t}$

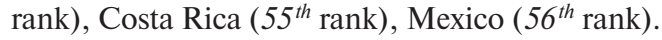

As the analysis showed, in the GII ranking for 2019, 17 of 25 first places are held by European countries. Europe is particularly strong in terms of human capital, research, infrastructure, and business development.

European countries are ahead in almost half of the indicators based on which the Global Innovation Index (GII) is calculated, including the share of highly qualified specialists in total employment, cooperation in university and industry research structures, the number of patent applications and scientific and technical articles and the quality of scientific publications.

The main factors contributing to the innovative development of the country, in our opinion, are resources of innovation (human capital, infrastructure, institutions, market and business stability) [1] and the quality of the innovation environment, which can have a reinforcing, supportive or deterrent effect, depending on the degree of its development.

Therefore, it is necessary to study in more detail the resources of innovation and the quality of the innovation environment in order to identify ways to increase the innovative potential of the country.

To date, in the economic literature, there is no uniform approach to understanding the essence of the concept of "innovative environment". This term is considered as a set of institutes of innovative transformations in all spheres of society's life and as a factor in the development of education and science in a transformational economy [4, 5]. Bondarenko [6] notes that "... the innovation environment is a socio-economic space, which is created in a certain way, and allows increasing and strengthening the relationship between institutions, helps create the necessary communications between elements of the innovation system and speeds up the processes for the formation of an innovative economy". According to the definition of the Business dictionary [7], the innovation environment is a certain socio-economic, organizational, legal and political environment, which provides or constrains the development of innovation activities for the implementation of and increase in innovation potential.

We consider that such an interpretation does not have a clear definition of the specifics of the innovation environment, but is considered as an interrelation of individual environments, which, on the one hand, facilitates the study of development/constrain factors of the innovation potential for individual environmental components, and, on the other, it requires the development of an additional mechanism for selecting "control points" of the innovation potential.

On the other hand, according to $[8,9]$, the innovation environment is a combination of mechanisms, tools, processes, infrastructural elements and human capital, providing innova- tion activity. In this context, the mechanisms and tools which provide innovation activity are defined.

Summarizing, regarding the problem studied in the article, it is advisable to formulate a definition of the innovation environment as a combination of internal factors and external conditions of a participant in innovation activity, which are interrelated socio-economic elements and their interactions, which are providing synergistic effect and aimed at generating innovation.

According to Fagerberg $[5,8]$ the level of development of the innovation environment, its compliance with the quality of innovation processes and the level of activity of innovation is determined by the level of development of innovation potential of the country. This statement confirms the relationship between the objects of "innovation environment" and "innovation potential" and makes it appropriate to conduct a more thorough study on the impact of factors on the innovation potential of the country in order to determine ways to improve it.

It should be noted that the innovation potential of each environment is determined by the set of available resources and conditions required for sustainable and effective development of its subjects and ensuring their effective cross-sectoral coordination within the optimal trajectory of the innovation environment.

Table 1 is compiled according to The Global Innovation Index and The Global Competitiveness Report and presents the ranking of European countries on GII, as well as on the main indicators of resources of innovation in the context of the effectiveness of the R\&D conduct and use, as the main tool for increasing the innovative potential of the country.

The statistical data in Table 1 indicate the concentration of innovations in the richest countries in Europe, which according to the World Bank Income Group Classification-2019 [3], are high-income countries. Based on the presented data, it can also be argued that the level of integration processes of the country creates a significant advantage for the development of its innovation environment, as it facilitates communication and knowledge exchange between specialized organizations. The characteristics of any national innovation system depend almost entirely on basic economic and political system (institutional conditions) in which it was formed.

Analysis of national innovation systems of European countries which, according to GII, hold the highest positions in it shows that they are characterized by stimulating European cooperation between various R\&D actors (research centers, universities, private companies), coordination of innovation policies - Members of the EU, developing a common strategy to disseminate the best national experience of innovation $[4,9]$.

While the European countries, which, according to the GII, hold the lowest positions in it (Russian Federation $46^{\text {th }}$ rank, Ukraine $-47^{\text {th }}$ rank, Moldova $-58^{\text {th }}$ runk, Belarus $-72^{\text {nd }}$ runk, Albania $-83^{\text {rd }}$ rank), both in terms of the general indicator and indicators characterizing the level of scientific research and development in the country shows that the key problem is the functioning of independent research institutions and organizations that are not integrated into other segments of the innovation system, i.e. the national innovation systems of these countries are characterized by a low level of coordination between the research and development sector, the higher education sector and the business sector.

The innovative type of development of countries, which hold the highest ranks in the ranking, and the active production and use of $R \& D$ results in the economy determine their high level of competitiveness in the global market. The phenomenon of research potential concentration is supported by the so-called "brain drain" - head hunting of talented scientists from poorer countries by academic institutions in countries, which are more economically developed.

It should be noted that the key point in the state's position regarding $R \& D$ as a resource of innovations, which forms new knowledge and technologies, in current conditions should be 
Table 1

Ranking of European countries by indicators of the Global Innovation Index, Innovation Resources, Global Competitiveness Index and the World Bank by income groups [1-3]

\begin{tabular}{|c|c|c|c|c|c|c|c|c|}
\hline Indicator/country & $\begin{array}{l}\text { GII } \\
\text { Rank }\end{array}$ & $\begin{array}{c}\text { Research \& } \\
\text { development } \\
\text { Rank }\end{array}$ & $\begin{array}{c}\text { GERD } \\
\text { performed } \\
\text { by business }\end{array}$ & $\begin{array}{c}\text { GERD } \\
\text { financed } \\
\text { by business }\end{array}$ & $\begin{array}{c}\text { GERD } \\
\text { financed } \\
\text { by abroad }\end{array}$ & $\begin{array}{l}\text { University/ } \\
\text { industry research } \\
\text { collaboration }\end{array}$ & $\begin{array}{l}\text { World Bank } \\
\text { Income Group } \\
\text { Classification }\end{array}$ & $\begin{array}{c}\text { The Global } \\
\text { Competitiveness } \\
\text { Report }\end{array}$ \\
\hline Switzerland & 1 & 4 & 5 & 10 & 41 & 3 & HI & 5 \\
\hline Sweden & 2 & 6 & 4 & 14 & 55 & 9 & HI & 8 \\
\hline Netherlands & 4 & 12 & 17 & 24 & 30 & 4 & HI & 4 \\
\hline United Kingdom & 5 & 9 & 18 & 25 & 26 & 7 & HI & 9 \\
\hline Finland & 6 & 10 & 10 & 15 & 35 & 5 & HI & 11 \\
\hline Denmark & 7 & 8 & 9 & 13 & 46 & 19 & HI & 10 \\
\hline Germany & 9 & 7 & 7 & 7 & 60 & 6 & HI & 7 \\
\hline Israel & 10 & 2 & 1 & 54 & 3 & 2 & HI & 20 \\
\hline Ireland & 12 & 20 & 27 & 30 & 16 & 11 & HI & 24 \\
\hline France & 16 & 11 & 13 & 20 & 51 & 30 & HI & 15 \\
\hline Luxembourg & 18 & 31 & 28 & 32 & 69 & 13 & HI & 18 \\
\hline Norway & 19 & 19 & 20 & 40 & 45 & 22 & HI & 17 \\
\hline Iceland & 20 & 24 & 14 & 51 & 14 & 24 & HI & 26 \\
\hline Austria & 21 & 18 & 6 & 21 & 24 & 16 & $\mathrm{HI}$ & 21 \\
\hline Belgium & 23 & 16 & 11 & 12 & 22 & 12 & HI & 22 \\
\hline Estonia & 24 & 44 & 34 & 31 & 31 & 48 & HI & 31 \\
\hline New Zealand & 25 & 23 & 33 & 38 & 50 & 21 & HI & 19 \\
\hline Czech Rep. & 26 & 40 & 19 & 46 & 13 & 39 & HI & 32 \\
\hline Malta & 27 & 45 & 44 & & 38 & 42 & HI & 38 \\
\hline Spain & 29 & 21 & 32 & 33 & 47 & 59 & HI & 23 \\
\hline Italy & 30 & 22 & 23 & 23 & 44 & 41 & HI & 30 \\
\hline Slovenia & 31 & 25 & 15 & 6 & 41 & 46 & HI & 35 \\
\hline Portugal & 32 & 26 & 29 & 37 & 48 & 31 & HI & 34 \\
\hline Hungary & 33 & 34 & 22 & 17 & 21 & 53 & HI & 47 \\
\hline Latvia & 34 & 53 & 56 & 65 & 12 & 78 & HI & 41 \\
\hline Slovakia & 37 & 47 & 39 & 34 & 38 & 79 & HI & 42 \\
\hline Lithuania & 38 & 46 & 47 & 47 & 19 & 37 & HI & 39 \\
\hline Poland & 39 & 37 & 30 & 22 & 63 & 92 & HI & 37 \\
\hline Bulgaria & 40 & 51 & 38 & 39 & 10 & 69 & UM & 49 \\
\hline Greece & 41 & 36 & 36 & 36 & 27 & 122 & HI & 59 \\
\hline Croatia & 44 & 52 & 40 & 42 & 37 & 111 & HI & \\
\hline Montenegro & 45 & 83 & 71 & 61 & 60 & 61 & UM & 73 \\
\hline Russian Fed. & 46 & 30 & 31 & 58 & 73 & 40 & UM & 43 \\
\hline Ukraine & 47 & 54 & 50 & 59 & 15 & 64 & LM & 85 \\
\hline Georgia & 48 & 75 & & & 28 & 98 & LM & 74 \\
\hline Romania & 50 & 77 & 48 & 27 & 43 & 74 & $\mathbf{U M}$ & 51 \\
\hline Serbia & 57 & 50 & 45 & 75 & 18 & 76 & UM & 72 \\
\hline Moldova, Rep. & 58 & 84 & 70 & 70 & 67 & 109 & LM & 86 \\
\hline Belarus & 72 & 61 & 41 & 41 & 29 & & UM & \\
\hline Bosnia and Herzegovina & 76 & 79 & 67 & 62 & 23 & 114 & UM & 92 \\
\hline Albania & 83 & 103 & & 85 & 51 & 73 & UM & 81 \\
\hline
\end{tabular}

* GERD - Gross expenditure on R\&D

the optimal allocation of budget resources, the amount of which is limited.

As for the structure of financing of innovative developments, the following tendencies can be distinguished. High- income countries are characterized by a high level of involvement of the business sector in financing innovative developments. However, the degree of public sector participation is also very significant, demonstrating that the high level of fund- 
ing for innovative developments by the business sector does not hinder government funding. There is no substitution effect; on the contrary, there is high investment by business along with a high level of public funding $[4,9]$.

As shown by the analysis [1], in lower-middle income and upper-middle income countries, external sources are the basis for fundamental research funding, because private firms, as a rule, support with their capital only those technologies, which are close to entering the market, relying on future profit, and thus turn scientific discoveries into a market product. Thus, for such countries, it is extremely important to find ways of attracting private capital in the implementation of fundamental research, since the role of the financial infrastructure is to diversify the financial resources of national innovation systems in accordance with the requirements of demand and the strategic goals of state innovation policy.

Considering the fact that highly developed countries have better knowledge of adapted infrastructure for solving new scientific problems, in particular, developed legal support and scientific and technological complexes, they will receive significant competitive advantages from international scientific and technical cooperation.

As shown by the analysis of the Ukrainian indexes dynamics in the GII from 2013 to 2018, there is a positive growth trend in the innovative potential of the country, which is reflected in Table 2.

Let us note that the resources of innovation ("input" indicators) should be considered as indicators, assessing the current state of the innovation potential of the country, whereas the innovation results ("output" indicators) are indicators, assessing the actual implementation of the innovation potential in the process of practical activities [1]. The coefficient of innovation efficiency is calculated as the ratio of innovation results to resources of innovation, and thus reflects the aggregated performance of the country's innovation activity with certain innovation potential.

The data in Table 2 indicate that the performance of innovation activity of Ukraine at a given level of innovation potential by 2013-2018 has a steady growth tendency (31 ${ }^{\text {st }}$ rank in $2013,5^{\text {th }}$ rank in 2018). These results confirm that environmental factors, in particular, political and economic crises, caused by military actions and the antiterrorist operation in the east of the country (since 2014), do not significantly slow down its innovative development ( $71^{\text {st }}$ rank in $2013,43^{\text {rd }}$ rank in 2018).
Table 2

Ukrainian indexes dynamics in the GII from 2013 to 2017

\begin{tabular}{|c|c|c|c|c|}
\hline Year & GII & $\begin{array}{c}\text { Resources of } \\
\text { innovations }\end{array}$ & $\begin{array}{c}\text { Results of } \\
\text { innovations }\end{array}$ & $\begin{array}{c}\text { Innovation } \\
\text { efficiency }\end{array}$ \\
\hline 2013 & 71 & 83 & 58 & 31 \\
\hline 2014 & 63 & 88 & 46 & 14 \\
\hline 2015 & 64 & 84 & 47 & 15 \\
\hline 2016 & 56 & 76 & 40 & 12 \\
\hline 2017 & 50 & 77 & 40 & 11 \\
\hline
\end{tabular}

However, it should be noted that despite the increase in the ranking of Ukraine by all components of the GII, the indicator " resources of innovation", which is an "input" indicator of innovations, remains low ( $75^{\text {th }}$ among 126 countries), which indicates a rather low level of its innovative potential and determines the peculiarity of the formation of patterns of innovative development of Ukraine. This determines the feasibility of a more detailed analysis of this indicator components in order to identify its "bottlenecks".

Based on the analysis $[5,7,10]$, in the context of this study, we propose to consider the innovation potential as an integral concept of scientific and production potentials, which, on the one hand, contain a specific set of resources necessary for innovation activity, and on the other, are based on ensuring the economic relations of business entities regarding the implementation of innovative activities. The results are presented in Table 3.

Let us note that the scientific literature analysis [11, 12] found that today there is no uniform definition for the concept of "institutional structure". Moreover, quite often this concept is identified with the related category of "institutional environment". To define these categories, the authors use the following concepts: institution, rule, norm, custom, institutional framework, set of agreements. Wherein, according to the systems approach, the structure is a stable ordering in space and time of elements and relations between them [13, 14].

Thus, in this study, we suggest understanding the concept of institutional structure as a set of formal and informal institutions which determine the main directions of social development, have stable orderliness, a certain level of interaction, specific rules and mechanisms for their implementation.

The dynamics of "input" indicators of the development level of Ukraine's innovation potential institutional structure for 2014-2019

\begin{tabular}{|c|c|c|c|c|c|c|}
\hline Indicators /year & 2014 & 2015 & 2016 & 2017 & 2018 & 2019 \\
\hline \multicolumn{7}{|c|}{ Resources of innovations ("input" indicators) } \\
\hline \multicolumn{7}{|l|}{ Institute of Research and development regulation } \\
\hline - Researchers & 46 & 46 & 44 & 49 & 49 & 50 \\
\hline - Gross expenditure on R\&D & 47 & 44 & 54 & 54 & 62 & 67 \\
\hline \multicolumn{7}{|c|}{ Institute for Financial Support of Innovation Development } \\
\hline - GERD financed by abroad & 17 & 17 & 21 & 23 & 19 & 15 \\
\hline - GERD financed by business enterprise & 29 & 51 & 44 & 35 & 47 & 59 \\
\hline \multicolumn{7}{|l|}{ Institute of Innovations Creation and Development } \\
\hline - University/industry research collaboration & 75 & 72 & 72 & 55 & 70 & 64 \\
\hline - GERD performed by business enterprise & 35 & 36 & 40 & 40 & 46 & 50 \\
\hline \multicolumn{7}{|l|}{ Institute of Personnel Support of Innovative Potential } \\
\hline - Tertiary enrolment & 11 & 13 & 10 & 12 & 12 & 14 \\
\hline - Graduates in science and engineering & 23 & 20 & 27 & 28 & 21 & 33 \\
\hline - Employment in knowledge-intensive services & 37 & 39 & 39 & 30 & 33 & 33 \\
\hline
\end{tabular}


The data in Tables 1, 2 and 3 indicate that the infrastructure for innovation support in the country does not have the required level of innovation support services, does not receive sufficient funding, and does not have the methodologies and knowledge of providing innovation support services on the appropriate level. In addition, elements of the innovation infrastructure are not sufficiently interconnected and are not actively involved in international networks due to the lack of awareness of their existence.

Ukraine is also characterized by a low level of research results commercialization since there are no effective mechanisms for mediating technology transfer with technology providers and their customers.

Among the resources of innovation listed in Table 3, the "bottlenecks", which constrain the increase of the innovative potential of a country, are:

1. Low cumulative research expenditure $\left(47^{\text {th }}\right.$ rank in 2014 , $67^{\text {th }}$ rank in 2019);

2. Low cooperation between universities and industry (75 ${ }^{\text {th }}$ rank in 2014, 55 th rank in 2017 and $64^{\text {th }}$ rank in 2019).

Thus, the peculiarities of formation of the innovative development regularities are established based on the "input" indicators comprehensive analysis for the institutional structure development level of the innovative potential of a country, which is carried out in the following stages:

1. Ranking of countries by the main indicators of resources and/or results of innovation in order to establish general tendencies in the development of innovative systems of countries and identify factors, which increase/constrain their innovative potential (a general list of factors, which is typical for the group of countries by the criterion of geographical localization has been formed: Europe, Southeast Asia and Oceania, Central and South Asia, Western Asia and North Africa, Sub-Saharan Africa, North America, Latin America and the Caribbean).

2. Analyzing the dynamics of indicators (resources of innovations, results of innovations and efficiency of innovations) of a certain country in order to define a "bottleneck" and, at the next stage, conduct a detailed analysis of these indicator components (indicators of "input" or "output").

3. Analysis of indicators (components of the indicator established in stage 2) in order to identify the "bottlenecks", which constrain the innovative potential of the country.

In [15] the factors are indicated which constrain the development of Ukraine's innovative potential, such as: the low level of international cooperation in the innovation sphere; lack of human resources; lack of measures for integration of science and production; the imperfection of the legal framework of innovation and regulation of the market for innovation. As Bondarenko [6] notes, "the main sources of the in- novation potential constraints are the state and the business environment. The state does not create conditions conducive to the development of the business environment, and also does not pay enough attention to the environment of knowledge production, which is the basis for innovation. The existing innovative developments do not reach the enterprises due to the inefficiency of the knowledge transfer channels. In turn, the business environment shows a low demand for domestic innovations, does not focus on innovative development [6].

Thus, our comprehensive analysis of the "input" indicators of the institutional structure development level of the country's innovation potential confirms the above-mentioned hypothesis that today Ukraine has a very low level of intersectoral cooperation "higher education-science-business", which is based on the lack of innovation environment subjects activity due to lack of trust, which is a consequence of poor management and insufficient level of practical cooperation of the science and the business sectors.

The above is the basis for building a conceptual model of the innovation environment effective functioning, which, unlike the existing models $[5,16]$, is aimed at increasing the intersectoral coordination of its subjects with a view to their adaptation (actualization) to the actual conditions of a country's development (Figure). Let us note that the actual conditions of a country's development should be understood as external and internal factors in which it operates in the operational period, and which need updating in the strategic period [17].

In this model, the institutions, which support, stimulate and regulate the innovation environment activity are presented in such aspects as the Institute of Innovation Activity Legal Regulation (government bodies ensuring the creation of conditions for the innovation activity implementation), which regulates the subjects of innovation, provides the formation of innovation activity regulatory framework and state registration of rights for intellectual property. The financial support for innovation activity (the main sources of financing for innovation are the state, business (their own funds), banks, foreign investments, grants) is provided by the Institute for Innovation Activities Funding. The Institute of Organizational Support for Innovation Activities promotes the establishment of cooperation between the subjects of innovation activity, as well as the transfer, storage and exchange of its results. The Institute of Information Support for Innovation Activities provides the spread of information to enhance the intersectoral cooperation "higher education-science-business" from two sides: business acts as a "customer" of innovative developments; scientists "implement" their innovative developments.

Let us note that the effective functioning of the proposed conceptual model is based on the following principles:

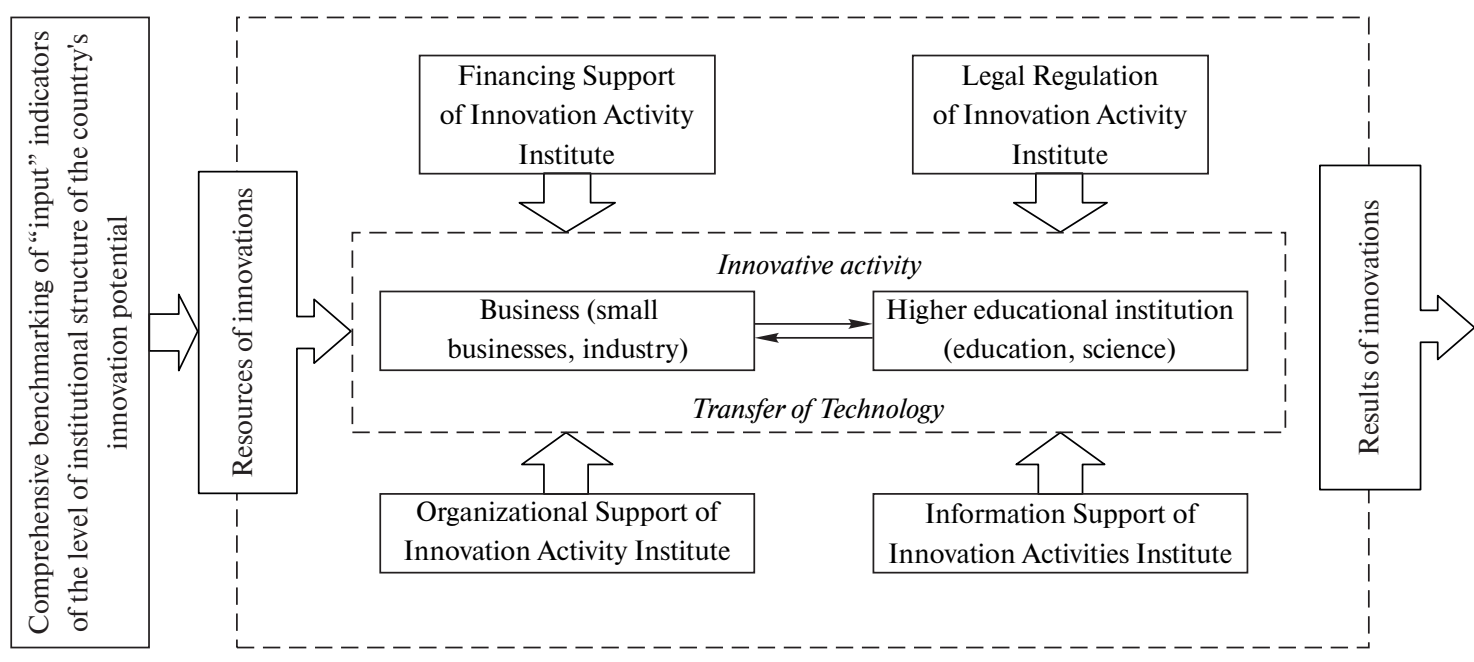

Fig. The conceptual model of the innovation environment effective functioning, which is based on the increasing the intersectoral coordination of its subjects 
- coordination of innovation and technological activity of the innovation infrastructure subjects, considering the existing institutional capacities;

- creation of a balanced resource exchange system "business - higher education institution" - innovative activity technology transfer;

- creation of the tools environment for start-up and development of effective cooperation "business - higher education institution"; ment;

- regulatory support of the innovation entities develop-

- diversification of financing innovation sources with an increase in the share of public funding;

- ensuring the continuous interaction of resources of innovation, which form the innovative potential (intellectual, financial, personnel, informational, organizational, material and technical resources) to achieve a synergistic effect, the result of which exceeds the total efficiency of functioning of individual components.

Conclusions. Based on the study, it can be argued that the use of new knowledge in the innovation processes, which are becoming more and more dynamic both in the whole world and in Europe, is the basis for the sustainability of their socioeconomic development.

In this case, the fact is crucially important that the effectiveness of development in modern society is achieved not only through the development of science and industry, but also by ensuring the effective flow of the entire innovation cycle. The equally important components of this cycle are obtaining new knowledge, transferring it to the manufacturing sector of the economy and further use in production, i.e. the establishment of the correct vector of intersectoral cooperation "higher education-science-business".

Despite the increased level of innovation activity there is a mismatch between the pace of development of new products (innovation results) and the use of new technologies (innovation resources), which is the peculiarity of the formation of patterns of innovative development of Ukraine.

Thus, the established "bottlenecks", which constrain the increase in the country's innovative potential and the developed conceptual model for the effective functioning of the innovation environment, which is based on increasing the intersectoral coordination of its subjects, determine the implementation of the following main strategic goals of its development:

- the creation of optimal conditions for interaction between the subjects of the innovation environment "higher education-science-business" for the implementation of the most promising projects on the formation and development of tools, mechanisms and technologies in order to increase the share of innovative products in the country;

- transformation of approaches to the funding of innovation activities on the basis of a simultaneous increase in the share of state funding and a reduction in the share of foreign investments in order to prevent the "drain" of developments abroad, and, conversely, their implementation and use in Ukraine.

Further work involves the development of an effective mechanism for the commercialization of scientific and technological developments for Ukraine, as an effective tool to enhance its innovative potential. It is assumed that this mechanism will be developed on the basis of studying the commercialization experience for scientific and technical developments of the world's leading countries and simultaneously neutralizing the "bottlenecks" identified in this study.

\section{References.}

1. The Global Innovation Index (2019). Retrieved from https:// www.globalinnovationindex.org/analysis-indicator.

2. The Global Competitiveness Report 2019 (2019). Retrieved from https://www.weforum.org/reports/global-competitiveness-report-2019.
3. World Bank Income Group Classification-2019. World Bank (2019). Retrieved from https://datahelpdesk.worldbank.org/ knowledgebase/articles/906519-world-bank-country-andlending-groups.

4. Bilyk, R. S. (2015). Features of the innovation environment development in Ukraine in terms of global competition. Visnyk Dnipropetrovskoho Universytetu: Management of Innovations, (4), 27-35.

5. Fagerberg, J. (2018). Innovation, Economic Development and Policy: Selected Essays, Edward Elgar, Cheltenham. https://doi.org/10.1111/rsp3.12234.

6. Bondarenko, S. A. (2017). Analytical assessment of the innovative environment of ukraine and its influence on the development of wine producers. Problems of systemic approach in the economy, 58(2), 61-66.

7. Business vocabulary (2019). Retrieved from http://www. businessvoc.ru/.

8. Fagerberg, J., Lundvall, B. A., \& Srholec, M. (2018). Global Value Chains, National Innovation Systems and Economic Development. The European Journal of Development Research, 3(22), 533-556. https://doi.org/10.1057/s41287-018-0147-2.

9. Al-kfairy, M., Khaddaj, S., \& Mellor, R. B. (2020). Evaluating the effect of organizational architecture in developing science and technology parks under differing innovation environments. Simulation Modelling Practice and Theory, 100. https:// doi.org/10.1016/j.simpat.2019.102036.

10. Litvinenko, I. L. (2016). Conceptual basis for the formation of state innovation policy and the development of national innovation systems. Innovative development of economy, 34(4), 59-72.

11. Kraus, N. (2015). Innovative economy: definition of concept and institutional basis of development. Scientific Bulletin of Mukachevo State University. Series "Economics", 4(2(1)), $36-42$.

12. García, A., García, M., \& Dias, J. (2018). The individual's perception of institutional environments and entrepreneurial motivation in developing economies: Evidence from Cape Verde. South African Journal of Economic and Management Sciences, 21(1). https://doi.org/10.4102/sajems.v21i1.2377.

13. Tarapuez, E., \& Ramiro, B. (2019). Formal Institutional Factors Influencing the Entrepreneurial Intent in Quindío. RAIS Conference Proceedings. The $14^{\text {th }}$ International RAIS Conference on Social Sciences and Humanities. http://doi. org/10.2139/ssrn.3459587.

14. Litvinenko, N. I. (2015). Institutional components of socioeconomic development of the country. Dnipro: National Mining University.

15. Kurylo, L.I., Slyozko, T.M., \& Udovychenko, S. M. (2015). Institutional factors of innovative economy in agriculture. Economic Analysis, 21(2), 144-151.

16. Jakšić, M. (2018). Inclusive Institutions for Sustainable Economic Development. Journal of Central Banking Theory and Practice, 7(1). https://doi.org/10.2478/jcbtp-2018-0001. 17. Bukreieva, D. S. (2017) Controlling - the mechanism of effective enterprise management. Dnipro: National Mining University.

\section{Особливості формування інноваційного середовища країни на основі індикативного аналізу ресурсів інновацій}

\section{Д. С. Букреєва}

Національний технічний університет «Дніпровська політехніка», м. Дніпро, Україна, e-mail: bukreieva.d.s@nmu.one

Мета. Виявити закономірності й тенденції впливу факторів на інноваційний потенціал країни з метою визначення шляхів його підвищення на основі вивчення індикаторів «входу» рівня розвитку інституціональної 
структури інноваційного потенціалу країни й розробки концептуальної моделі ефективного функціонування інноваційного середовища.

Методика. При вирішенні поставлених завдань були використані наступні методи: наукового абстрагування - при визначенні основних проблем розвитку національних інноваційних систем; критичного аналізу, узагальнення, систематизації - для оцінки ефективності інноваційної політики країн та їх порівняння; ранжування та статистичного аналізу - для визначення взаємозв'язку окремих показників глобального інноваційного індексу й рівня розвитку країни.

Результати. Проведено ранжування Європейських країн за основними показниками ресурсів інновацій у розрізі ефективності проведення й використання наукових досліджень і розробок. Визначені «вузькі» місця, що перешкоджають підвищенню інноваційного потенціалу України, на основі аналізу індикаторів «входу» рівня розвитку його інституціональної структури. Продемонстрована висока ступінь залежності економічного розвитку країни від іiі інноваційного потенціалу. Доведено, що фактори зовнішнього середовища, зокрема політична та економічна кризи, обумовлені військовими діями та проведенням антитерористичної операції на сході країни, не є такими, що суттєво можуть гальмувати ії інноваційний розвиток. Сформульовані основні напрями підвищення інноваційного потенціалу України на основі ефективного управління ресурсами інновацій. Розроблена концептуальна модель ефективного функціонування інноваційного середовища, направлена на підвищення міжсекторної координації його суб'єктів з метою їх адаптації до фактичних умов розвитку країни.

Наукова новизна. Встановлені особливості формування закономірностей інноваційного розвитку на основі комплексного порівняльного аналізу індикаторів «входу» рівня розвитку інституціональної структури інноваційного потенціалу країни, що дозволило встановити фактори, які $є$ визначальними у підвищенні інноваційного потенціалу України, та, на цій основі, розробити концептуальну модель ефективного функціонування інноваційного середовища.

Практична значимість. Отримані результати дозволили сформулювати основні пріоритетні напрями розвитку в галузі управління інноваціями з урахуванням нейтралізації «вузьких» місць інноваційного потенціалу країни.

Ключові слова: інноваційний потенціал, глобальний інноваційний індекс, ресурси інновацій, інноваційне середовище, індикативний аналіз

\section{Особенности формирования инновационной среды страны на основе индикативного анализа ресурсов инноваций}

\section{Д. С. Букреева}

Национальный технический университет «Днепровская политехника», г. Днепр, Украина, e-mail: bukreieva.d.s@ nmu.one
Цель. Выявить закономерности и тенденции влияния факторов на инновационный потенциал страны с целью определения путей его повышения на основе изучения индикаторов «входа» уровня развития институциональной структуры инновационного потенциала страны и разработки концептуальной модели эффективного функционирования инновационной среды.

Методика. При решении поставленных задач были использованы следующие методы: научного абстрагирования - при определении основных проблем развития национальных инновационных систем; критического анализа, обобшения, систематизации - для оценки эффективности инновационной политики стран и их сравнения; ранжирования и статистического анализа - для определения взаимосвязи отдельных показателей глобального инновационного индекса и уровня развития страны.

Результаты. Проведено ранжирование европейских стран по основным показателям ресурсов инноваций в разрезе эффективности проведения и использования научных исследований и разработок. Определены «узкие» места, препятствующие повышению инновационного потенциала Украины, на основе анализа индикаторов «входа» уровня развития институциональной структуры ее инновационного потенциала. Продемонстрирована высокая степень зависимости экономического развития страны от ее инновационного потенциала. Доказано, что факторы внешней среды, а именно политический и экономический кризис, обусловленные военными действиями и проведением антитеррористической операции на востоке страны, не являются таковыми, которые значительно могут тормозить ее инновационное развитие. Сформулированы основные направления повышения инновационного потенциала Украины на основе эффективного управления ресурсами инноваций. Разработана концептуальная модель эффективного функционирования инновационной среды, направленная на повышение межсекторной координации его субъектов с целью их адаптации к фактическим условиям развития страны.

Научная новизна. Установлены особенности формирования закономерностей инновационного развития на основе комплексного сравнительного анализа индикаторов «входа» уровня развития институциональной структуры инновационного потенциала страны, что позволило установить факторы, которые являются определяющими в повышении инновационного потенциала Украины, и, на этой основе, разработать концептуальную модель эффективного функционирования инновационной среды.

Практическая значимость. Полученные результаты позволили сформулировать основные приоритетные направления развития в области управления инновациями с учетом нейтрализации «узких» мест инновационного потенциала страны.

Ключевые слова: инновационный потенциал, международный инновационный индекс, ресурсы инноваций, инновационная среда, индикативный анализ

Recommended for publication by O.V. Yermoshkina, Doctor of Economic Sciences. The manuscript was submitted 27.12.19. 